\title{
PREVALENCE RATE OF CHLAMYDIA TRACHOMATIS INFECTION IN EGYPTIAN INFERTILE WOMEN
}

\author{
${ }^{1}$ Magda Ramadan Abdu Alwadood - ${ }^{1}$ Manal M. Darwish - ${ }^{2}$ Ali Shoker \\ ${ }^{1}$ Departments of medical Microbiology and Immunology and Gynecology and Obstetrics \\ ${ }^{2}$ Faculty of Medicine, Ain Shams University Cairo, Egypt.
}

\begin{abstract}
Chlamydia trachomatis is one of the most common curable bacterial sexually transmitted infections (STIs) worldwide, and its complications in infected women in terms of pelvic inflammatory disease (PID), infertility and ectopic pregnancy among others with this infection highlights the need of its diagnosis in women with a history of infertility and recurrent spontaneous abortion for their better management.the present study evaluates the relationship between either past or current $C$. trachomatis infection in asymptomatic Egyptian females with unexplained infertility. This may be needed to be highlighted to attract the attention of clinical investigators. In addition the study compares the effectiveness of the point of care (POC) chlamydia test with polymerase chain reaction (PCR) as a potential tool for rapid Chlamydia diagnosis and screening .In the present study we enrolled women attending the gynecology outpatient department (OPD) of Ain shams educational hospital in the period from January 2013 to September 2013.The case group comprised of seventy five married infertile women. control group of twenty patients who were attending the clinic for other gynecologic purposes The clinician team did a routine gynecological per speculum examination to record signs of infection and collected two cervical swabs and blood samples, The first swab was shaken on a vortex mixerThe contents of the tube were used for direct Geimsa staining and point of care testing. The second swab was shaken on a vortex mixer then it was removed after pressing against the tube wall. And the content was preserved at $-70^{\circ} \mathrm{C}$ until used for DNA extraction and PCR Chlamydia rapid test (CRT) wasperformed,The detection of IgG antibodies against C. trachomatis was performed by using a commercial ELISA kit . Seventy five infertile women and twenty control females were tested for current $C$,trachomatis infection by PCR, C.trachomatis POC test and geimsa staining. AS well as serum samples were collected to detect C.trachomatis specific IgG by ELISA. The Participants of the infertility cases were between 20-45 years old with a mean of (34.18 \pm 5.3 ) The overall prevalence of anti C trachomatis antibodies (ACTA) IgG in infertile women was $27 / 75(36 \%)$ in infertile women and 2/20 (10\%) in control group ,the difference was statistically significant $(\mathrm{P}<0.05)$ The overall prevalence of genital C.trachomatis by PCR was (22/75)29.3\% in infertile women and 1/20 (5\%) in control subjects versus $(18 / 75)$ $24 \%$ by C.trachomatis POCT. Sensitivity, specificity, Positive predictive value and Negative predictive value of C.trachomatis POCT was compared to PCR for the diagnosis of C.trachomatis infection and it revealed $81.8 \%, 98.1 \%, 94.7 \%$ and $92.9 \%$ respectively conclusion, we find a strong relationship between past and current C.trachomatis infection and infertility in a sample of Egyptian infertile women. No difference was found in the prevalence of current or past C.trachomatis infection and fertile controls. The Chlamydia rapid test achieves relatively high diagnostic sensitivity and provides results within 30 minutes. It is suitable as primary diagnostic tool for Chlamydia infection and in settings where PCR tests was limited or absent thus it could be used as a screening tool.
\end{abstract}




\section{INTRODUCTION:}

Data on the prevalence of Chlamydia trachomatis ( C. trachomatis) infection in the Middle East and North Africa (MENA) region remain scarce due to its limited research capacity and sociocultural sensitivity around sexually transmitted infections (STIs). ( Mc Farland et al., 2010) This challenge is further compounded by methodological limitations in available studies and by the logistical difficulty in conducting STI studies among women. (Abu-Raddad et al., 2010). Considering that $C$. trachomatis is one of the most common curable bacterial STIs worldwide, and its complications in infected women in terms of pelvic inflammatory disease (PID), infertility and ectopic pregnancy among others. (WHO. 2013) Chlamydial PID is the most important preventable cause of infertility and adverse pregnancy outcome. Based on the available studies, approximately $20 \%$ of women with chlamydial genital infection will develop PID, 3\% develop infertility, 2\% develop adverse pregnancy outcome. (Bohm et al., 2009; Carey et al., 2010)

Pramanik et al. (2012) suggested association between current C. trachomatis infection and infertility. Absence of signs and symptoms associated with this infection highlights the need of its diagnosis in women with a history of infertility and recurrent spontaneous abortion for their better management. El- Shorbagy et al. (2010) investigated genital Chlamydial infection incidence among high risk clinical conditions in Egyptian women and found that incidence of Chlamydial infection was $79.3 \%$ among cervicitis group, $33.3 \%$ among subjects with inflammatory smear, $75.2 \%$ among those with cervical condyloma, $82.6 \%$ among those with cervical intraepithelial neoplasia, 51.8\% among tubal infertility subjects, $77.2 \%$ among ectopic patients and $56.3 \%$ among subjects with preterm labor. The study mentioned that empirical treatment is recommended as the diagnosis is costly and usually not available. Among Egyptian infertile women, the prevalence of $c$. trachomatis infection ranged from 15\%-45\% depending on the method of diagnosis. Authors of previous studies concluded that $C$. trachomatis play a role in infertility, and should be considered in the investigations of these patients. (Chavez-Badiola et al., 2008 and Dutta $e t$ al., 2008). Siam and Hefzy (2011) reported that the prevalence of anti C.trachomatis IgG in asymptomatic infertile and control Egyptian women was (31.1\% and $17.5 \%$ respectively). Prevalence of current infection was $(4.4 \%$ and $7.5 \%)$ in infertile and fertile groups respectively ( $\mathrm{P}$ value $=0.87$ )and they concluded that no difference was found in the prevalence of current or past C.trachomatis infections between unexplained infertility cases and fertile controls. Although Bas et al., (2008) and Haggerty et al., (2010) mentioned that correlation of the c.trachomatis past and current infection with the infertility was clearly shown.

With the advent of nucleic acid amplification tests (NAATS), which can use non invasive specimens and have high sensitivity and specificity, improved detection and treatment of Chlamydia infection has been possible(Lau and Qureshi. 2002) However, these laboratory tests involve a delay between specimen submission and receipt of test results. This delay may lead to overtreatment (if patients are treated presumptively at their initial visit), postponed treatment) if the follow -up visit occurs days/ weeks later), or even lack of treatment (if patients are lost to follow up). (Schwebke et al., 1997)

Recently, several companies have developed point-of-care (POC) tests that provide rapid results for the detection of chlamydia at the index visit. This can dramatically reduce the time between testing and treatment, as well as increase treatment rates. (Swain et al., 2004) However, sensitivities of the three US Food and Drug Administration-approved POC chlamydia tests $(25 \%-65 \%)$ preclude more widespread use in clinical setting.(Huppert $\boldsymbol{e t}$ al., 2010). Nevertheless, POC tests can be beneficial in settings where patients do not 
reliably return for treatment. (Swain et al., 2004) Based on focus group discussions with clinicians, opinion leaders and public health professionals, and a recent clinician survey, an ideal POC test should have $\geq 90 \%$ sensitivity, require $\leq 30$ min to process, and cost $\leq$ US $\$ 20$ (Hsieh et al., 2011)

In Egypt the impact of current Chlamydia trachomatis (C. trachomatis) in reproductive health remains a neglected area of investigation. Thus the present study evaluates the relationship between either past or current $C$. trachomatis infection in asymptomatic Egyptian females with unexplained infertility. This may be needed to be highlighted to attract the attention of clinical investigators. In addition the study compares the effectiveness of the point of care (POC) chlamydia test with polymerase chain reaction (PCR) as a potential tool for rapid Chlamydia diagnosis and screening.

\section{MATERIALS AND METHODS:}

In the present study we enrolled women attending the Gynecology outpatient Department (OPD) of Ain shams educational hospital in the period from January 2013 to September 2013.

The case group comprised of seventy five (75) married infertile women. Primary infertility was forty six (46) and secondary infertility was twenty nine (29) patients. Primary infertility was defined as the inability to conceive after 1 or more years of regular coital activity without contraception, and secondary infertility was defined as the inability to conceive after 6 or more months of regular coital activity without contraception with a history of previous pregnancy The study included a control group of twenty patients (20) who were attending the clinic for other gynecologic purposes (abnormal uterine bleeding, ovarian cyst, intrauterine device insertion family planning. All the control group women had no complaint of infertility.

All cases were in the childbearing ages (20-45 years old). They were asymptomatic in terms of genital tract infection. None of the women received antibiotics or corticosteroids at least for 15 days before samples were taken. Basic infertility investigation included full detailed medical history and clinical examinations were done. During the standard infertility investigations, all female patients were checked for tubal patency and normal uterine cavity by hysterosalpingography (HSG) and/or laparoscopy and for the hormonal factor, including tests for ovarian, pituitary, thyroid and adrenal gland function. Sperm analysis was performed for their male partners.

\section{Specimen collection}

The clinician team did a routine gynecological per speculum examination to record signs of infection and collected two cervical swabs from 75 infertile and 20 control women, after cleaning the cervix with a dry cotton swab. Dacron swabs (Human For biochemical and diagnostic mbH,. Max-Plank-Ring 21-D-65205 wiesbaden-Germany) were used. They were preserved in $1.5 \mathrm{~mL}$ of a sterile medium containing $6.7 \mathrm{mg} / \mathrm{mL} \mathrm{KH} 2 \mathrm{PO} 4,3.36 \mathrm{mg} / \mathrm{mL}$ KH2PO4, $227 \mathrm{mg} / \mathrm{mL}$ sucrose, $50 \mathrm{mg} / \mathrm{L}$ gentamicin, $100 \mathrm{mg} / \mathrm{L}$ vancomycin and $50 \mathrm{mg} / \mathrm{L}$ amphotericin B.

One swab was shaken on a vortex mixer then it was discarded after pressing against the tube wall. The contents of the tube were used for direct Geimsa staining and point of care testing. The second swab was shaken on a vortex mixer then it was removed after pressing against the tube wall. The content was preserved at $-70^{\circ} \mathrm{C}$ until used for DNA extraction and PCR. 
Blood was collected by venipuncture, allowed to clot and serum was separated by centrifugation at room temperature. Specimens were stored $-20^{\circ} \mathrm{C}$ for detection of C.trachomatis specific IgG by ELISA circulating anti C.trachomatis IgG antibodies in the serum of both study and control groups.

\section{1) Extraction of DNA}

DNA was isolated from cervical specimen using a rapid non-enzymatic method. The cells were pelleted and resuspended in Tris- $\mathrm{MgCl}_{2}-\mathrm{KCl}$ buffer $(\mathrm{pH}=7.4)$ and treated with $10 \%$ sodium dodecyl sulphate at $55{ }^{\circ} \mathrm{C}$ for $10 \mathrm{~min}$ to lyse the cells. DNA was precipitated by $100 \%$ ethanol and eluted in Tris EDTA buffer (Lahiri and Nurnberger 1991). The method avoids the use of any organic solvents. This was achieved by salting out the cellular proteins by dehydration and precipitation with a saturated sodium chloride solution.

\section{PCR for diagnosis of C. trachomatis}

PCR was performed on extracted DNA using primers designed from the conserved region of MOMP gene of $C$. trachomatis with sense primer: $5^{\prime}$ GCC GCT TTG AGT TCT GCT TCC 3' and anti-sense primer: 5' GTC GAA AAC AAA GTC ACC ATA GTA 3' to amplify a 180 bp DNA fragment common to all serotypes (Mania -Pramanik et al., 2006) The reaction was carried out in a volume of $50 \mu \mathrm{l}$. It contained primers $(0.5 \mu \mathrm{m}$ each), $0.2 \mathrm{mM}$ dNTP's, PCR buffer (10 mM Tris buffer; $\mathrm{pH}=9$ ), 1.25 units of Taq polymerase, $10 \mu$ l of DNA specimen and the volume was adjusted with sterile distilled water. Positive and negative controls were also run in each experiment. Reaction was performed in a thermal cycler (Perkin Elmer 2400) as per the following protocol: initial denaturation was done for $5 \mathrm{~min}$ at $94{ }^{\circ} \mathrm{C}$. This was followed by 35 cycles of $30 \mathrm{~s}$ each of denaturation at $94{ }^{\circ} \mathrm{C}$, annealing at $55{ }^{\circ} \mathrm{C}$ and extension at $72{ }^{\circ} \mathrm{C}$ for $1 \mathrm{~min}$. The final extension step was carried out at $72{ }^{\circ} \mathrm{C}$ for $5 \mathrm{~min}$. The amplified products were run on $2 \%$ agarose gel, observed under a UV transilluminator while the results were being documented. Presence of $180 \mathrm{bp}$ repeat sequences in positive control specimen and its absence in the negative control indicated reaction had been completed satisfactorily.

\section{2) Point of care chlamydia rapid test}

Chlamydia Rapid Test CRT was performed. Version 6.1 of the Chlamydia Rapid Test (P/N 1200-20) instructions for use (C03-0008) was used. Shortly, each swab was subjected to extraction by sequential addition of $400 \mu 1$ of reagent $1,300 \mu l$ of reagent 2 , and $100 \mu \mathrm{l}$ of reagent 3 to the swab in a tapered sample preparation tube, with gentle mixing between additions. The sample preparation reagents were administered with unit dose pipettes. The extraction tube was then capped and used as a dropper to deliver 5 drops (approximately $100 \mu \mathrm{l}$ ) of the extracted sample to a tube containing the lyophilized amplification and detection reagents. The resulting mixture was agitated gently until a clear pink solution was obtained, after which the test strip, coated with a monoclonal antibody to chlamydial lipopolysaccharide (LPS) and including a procedural control, was added to the solution and allowed to stand for 25 minutes before the result was read. Each swab was subjected to one extraction. The test strip was used in the interpretation of the result; a clearly visible test line indicated a positive result, provided that the control line was also visible on the test strip. (CTK Biotech, USA,2006).

\section{3) Giemsa staining}

The typical chlamydia inclusions were described for the first time in Giemsa stained epithelial cells in the infected conjunctivae of primates (Munday 1980). Characteristic cytoplasmic inclusion bodies infected cells). 


\section{4) Serology}

The detection of $\operatorname{IgG}$ antibodies against C. trachomatis was performed by using a commercial ELISA kit (C.trachomatis IgG ELISA, Novum Diagnostics, Germany) Nova TecImmunodiagnostica, GMBH

In brief, microtitre wells precoated with $C$. trachomatis antigens were incubated with serum specimen at a 1:100 dilution so that any corresponding antibodies present in the serum would bind to the antigen to form complexes. After washing the wells to remove all unbound sample material, horseradish peroxidase (HRP) labeled antihuman IgG conjugate was added which would bind to captured Chlamydia specific antibodies. The immune complex formed by the bound conjugate was visualized by adding tetramethylbenzidine (TMB) substrate, which gives a blue colored reaction product. After terminating the reaction using a stop solution (Sulphuric acid, $0.2 \mathrm{~mol} / \mathrm{l}$ ), the absorbance of the end product, which is yellow in color, was read at $450 \mathrm{~nm}$ using an ELISA plate reader ( $\mu$ Quant, Bio-Tek Instruments Inc.). The intensity of this product is directly proportional to the amount of Chlamydia-specific IgG antibodies in the specimen. The specimens with O.D. higher than the cut-off value (0.250-0.900) were considered positive for Chlamydia-specific antibodies and used as an indicator of past Chlamydia infection

\section{RESULTS}

Seventy five infertile women and twenty control females were tested for current C,trachomatis infection by PCR, C.trachomatis POC test and geimsa staining. AS well as serum samples were collected to detect C.trachomatis specific IgG by ELISA. The Participants of the infertility cases were between 20-45 years old with a mean of $(34.18 \pm$

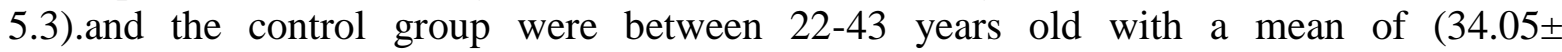
4.9).Difference between the two groups was not statistically significant. $(\mathrm{P}>0.05)$

The overall prevalence of anti $\mathrm{C}$ trachomatis antibodies (ACTA) IgG in infertile women was $27 / 75(36 \%)$ and $2 / 20(10 \%)$ the difference was statistically significant $(\mathrm{P}<0.05)$ (Table 1)and figure 1

Higher prevalence of anti $\mathrm{C}$ trachomatis $\mathrm{IgG}$ was found in the serum of primary infertility women $18 / 46(39.1 \%)$ than 2ry infertility women $9 / 29(31.03 \%)$. However, the difference between both groups was not significant $(\mathrm{P}=0.87)$ as shown in (Table 2) and figure 4. The overall prevalence of genital C.trachomatis by PCR was (22/75)29.3\% in infertile women and $1 / 20(5 \%)$ in control subjects versus (18/75) $24 \%$ by C.trachomatis POCT (Table 3) with a significant difference between both groups $(\mathrm{P}<0.05)$. Table 3 The prevalence of current genital C.trachomatis by PCR in 1ry infertility was (12/46) $26.1 \%$ and 2 ry infertility was 10/29 (34.4\%) with no significant difference between both groups. (Table 4) and figure 2

Sensitivity, specificity, Positive predictive value and Negative predictive value of C.trachomatis POCT was compared to PCR for the diagnosis of C.trachomatis infection and it revealed $81.8 \%, 98.1 \%, 94.7 \%$ and $92.9 \%$ respectively. (Table $5 \&$ 6) and figure 3

The control group showed only one case to be C.trachomatis PCR positive, on revising the clinical profile of this patient; it revealed that she was complaining of pelvic pain. (Table 7) 
(Table 8) described that tubal factor as a cause of infertility in the studied population was the highest 29/75 (38.7\%) and is highly correlated with C.trachomatis PCR positive results 13/29 (44.8\%) were positive C.trachomatis PCR.

(Table 9 )compare the causes of infertility between the 1ry and 2ry groups and their correlation with the C.trachomatis PCR positive results and it was found that tubal factor was the highly correlated with both groups with no significant difference

Table 1: Prevalence of anti Chlamydia antibodies ( $\operatorname{IgG})$ in serum of cases and control:

\begin{tabular}{|l|l|l|l|}
\hline Groups & $\begin{array}{l}\text { ACTA }(\operatorname{IgG})+\mathrm{ve} \\
\text { No \% }\end{array}$ & $\begin{array}{l}\text { ACTA (IgG) -ve } \\
\text { No. \% }\end{array}$ & Total \\
\hline Cases & $27(36 \%)$ & $48(64 \%)$ & 75 \\
\hline Controls & $2(10 \%)$ & $18(90 \%)$ & 20 \\
\hline
\end{tabular}

ACTA : Anti Chlamydia antibodies

Table 2: Prevalence of anti Chlamydia antibodies $(\mathrm{IgG})$ in serum of primary and secondary infertility

\begin{tabular}{|l|l|l|l|l|}
\hline Test & result & 1ry infertility & 2ry infertility & Total \\
\hline $\begin{array}{l}\text { Anti C.trachomatis } \\
\text { IgG }\end{array}$ & +ve cases & $18 / 46(39.1 \%)$ & $9 / 29(31.03 \%)$ & 27 \\
& & & & \\
& -ve cases & $28 / 46(60.9 \%)$ & $20 / 29(69 \%)$ & 48 \\
\hline
\end{tabular}

Table 3: Prevalence of Current genital $C$ trachomatis by PCR (POCT) and Geimsa stain

\begin{tabular}{|c|c|c|c|c|c|c|}
\hline $\begin{array}{l}\text { Group } \\
\text { No. }\end{array}$ & $\begin{array}{l}\text { PCR +ve } \\
\text { No. } \%\end{array}$ & $\begin{array}{l}\text { PCR -ve } \\
\text { No \% }\end{array}$ & $\begin{array}{l}\mathrm{POC}+\mathrm{ve} \\
\text { No } \%\end{array}$ & $\begin{array}{l}\text { POC-ve } \\
\text { No } \%\end{array}$ & $\begin{array}{l}\text { Geimsa } \\
\text { stain+ve } \\
\text { No } \%\end{array}$ & $\begin{array}{l}\text { Geimsa } \\
\text { stain -ve } \\
\text { No \% }\end{array}$ \\
\hline Cases (75) & $\begin{array}{l}22 \\
(29.3 \%)\end{array}$ & $\begin{array}{l}53 \\
(70.7 \%)\end{array}$ & $\begin{array}{l}18 \\
(24 \%)\end{array}$ & $\begin{array}{l}57 \\
(76 \%)\end{array}$ & $\begin{array}{l}7 \\
(9.3 \%)\end{array}$ & $\begin{array}{l}68 \\
(90.7 \%)\end{array}$ \\
\hline $\begin{array}{l}\text { Control } \\
\text { (20) }\end{array}$ & $\begin{array}{l}1 \\
(5 \%)\end{array}$ & $\begin{array}{l}19 \\
(95 \%)\end{array}$ & 0 & 20 & 0 & 20 \\
\hline Total ( 95) & $\begin{array}{l}23 \\
(24.2 \%)\end{array}$ & $\begin{array}{l}72 \\
(75.8 \%)\end{array}$ & $\begin{array}{l}18 \\
(18.9 \%)\end{array}$ & $\begin{array}{l}77 \\
(81.1 \%)\end{array}$ & $\begin{array}{l}11 \\
(11.6 \%)\end{array}$ & $\begin{array}{l}84 \\
(88.4 \%)\end{array}$ \\
\hline
\end{tabular}

Table 4: Comparison of Current genital C. trachomatis by PCR between primary and secondary infertile women

\begin{tabular}{|l|l|l|l|l|}
\hline test & results & 1ry infertility & 2ry infertility & Total \\
\hline $\begin{array}{l}\text { C. trachomatis } \\
\text { PCR }\end{array}$ & +ve cases & $12 / 46(26.1 \%)$ & $10 / 29(34.5 \%)$ & 22 \\
& -ve cases & $34 / 46(73.9 \%)$ & $19 / 29(65.5 \%)$ & 53 \\
\hline
\end{tabular}

Table 5: C.trachomatis point of care test (POCT) compared to the PCR for the diagnosis of C.trachomatis infection:

\begin{tabular}{|l|l|l|l|}
\hline PCR & C.trachomatis POCT & C.trachomatis POCT & Total \\
\hline
\end{tabular}




\begin{tabular}{|l|l|l|l|}
\hline & -ve cases & +ve cases & \\
\hline PCR -ve cases & 52 & 1 & 53 \\
\hline PCR +ve cases & 4 & 18 & 22 \\
\hline Total & 56 & 19 & 95 \\
\hline
\end{tabular}

Table 6: Sensitivity, specificity, positive predictive value and negative predictive value of POCT in comparison to PCR for the diagnosis of C.trachomatis infection:

\begin{tabular}{|l|l|l|}
\hline Sensitivity & $\begin{array}{l}\mathrm{TP} / \mathrm{TP}+\mathrm{FN} \\
18 / 18+4\end{array}$ & $81.8 \%$ \\
\hline pecificity & $\begin{array}{l}\mathrm{TN} / \mathrm{TN}+\mathrm{FP} \\
52 / 52+1\end{array}$ & $98.1 \%$ \\
\hline $\begin{array}{l}\text { Positive predictive } \\
\text { value (PPV) }\end{array}$ & $\begin{array}{l}\mathrm{TP} / \mathrm{TP}+\mathrm{FP} \\
18 / 18+1\end{array}$ & $94.7 \%$ \\
\hline $\begin{array}{l}\text { Negative } \\
\text { predictive value } \\
\text { (NPV) }\end{array}$ & $\begin{array}{l}\mathrm{TN} / \mathrm{TN}+\mathrm{FN} \\
52 / 52+4\end{array}$ & $92.9 \%$ \\
\hline
\end{tabular}

TP: true positive, FP: false Positive, TN: true Negative, FN: False negative

Positive predictive value (PPV) Negative predictive value (NPV)

Table 7: The control group clinical condition profile in correlation to $C$. trachomatis PCR results

\begin{tabular}{|l|l|l|l|}
\hline $\begin{array}{l}\text { Control group } \\
\text { causes }\end{array}$ & No of tested & $\%$ & $\begin{array}{l}\text { No.PCR } \\
\text { tested positive }\end{array}$ \\
\hline $\begin{array}{l}\text { Abnormal uterine } \\
\text { bleeding }\end{array}$ & 3 & $15 \%$ & 0 \\
\hline $\begin{array}{l}\text { Intrauterine device } \\
\text { check-up }\end{array}$ & 6 & $30 \%$ & 0 \\
\hline Pelvic pain & 5 & $25 \%$ & 1 \\
\hline Vaginal discharge & 6 & $30 \%$ & 0 \\
\hline Total & 20 & $100 \%$ & 1 \\
\hline
\end{tabular}

Table 8: Cause of infertility in the case group, with correlation to $C$. trachomatis PCR results

\begin{tabular}{|l|l|l|l|l|}
\hline Casegroup causes & No of cases & Percentile \% & $\begin{array}{l}\text { No.PCR } \\
\text { tested positive }\end{array}$ & Percentile \% \\
\hline Unexplained & 21 & $28 \%$ & 4 & $19.04 \%$ \\
\hline Tubal factor & 29 & $38.6 \%$ & 13 & $44.8 \%$ \\
\hline Male factor & 10 & $13.3 \%$ & 3 & $30 \%$ \\
\hline Non-ovulation & 15 & $20 \%$ & 2 & $13.3 \%$ \\
\hline Total & 75 & $100 \%$ & 22 & \\
\hline
\end{tabular}

Table 9: Cause of infertility in the primary and secondary infertility groups, with the results of polymerase chain reaction testing for Chlamydia trachomatis

\begin{tabular}{|l|l|l|l|l|l|l|}
\hline $\begin{array}{l}\text { Cause of } \\
\text { primary } \\
\text { \&secondary } \\
\text { group. }\end{array}$ & $\begin{array}{l}\text { Primary } \\
\text { infertility } \\
(n=46)\end{array}$ & $\begin{array}{l}\text { Primary } \\
\text { infertility } \\
\text { No of } \\
\text { positive } \\
\text { test }\end{array}$ & $\begin{array}{l}\text { Primary } \\
\text { infertility } \\
\%\end{array}$ & $\begin{array}{l}\text { Secondary } \\
\text { infertility } \\
(n=29)\end{array}$ & $\begin{array}{l}\text { Secondary } \\
\text { infertility } \\
\text { no of test } \\
\text { positive }\end{array}$ & $\begin{array}{l}\text { Secondary } \\
\text { infertility\% }\end{array}$ \\
\hline Unexplained & 14 & 1 & $7.14 \%$ & 7 & 3 & $42.9 \%$ \\
\hline
\end{tabular}




\begin{tabular}{|l|l|l|l|l|l|l|}
\hline Tubal factor & 19 & 8 & $42.1 \%$ & 10 & 5 & $50 \%$ \\
\hline Male factor & 6 & 1 & $16.6 \%$ & 4 & 2 & $50 \%$ \\
\hline Nonovulation & 7 & 2 & $28.5 \%$ & 8 & 0 & $0 \%$ \\
\hline Total & 46 & 12 & $26 \%$ & 29 & 10 & $34.4 \%$ \\
\hline
\end{tabular}

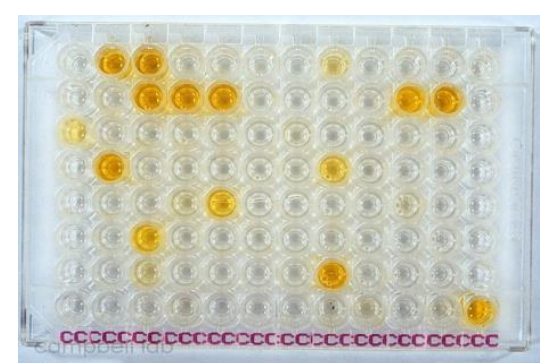

Figure 1 : The detection of $\operatorname{IgG}$ antibodies against $\mathrm{C}$. trachomatis was performed by using a commercial ELISA

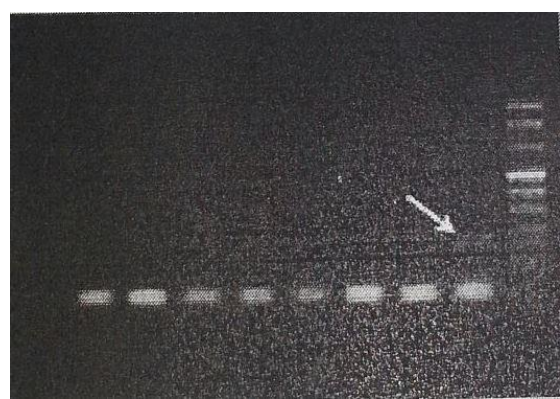

Figure 2 : PCR for diagnosis of Chlamidia Trachomatis

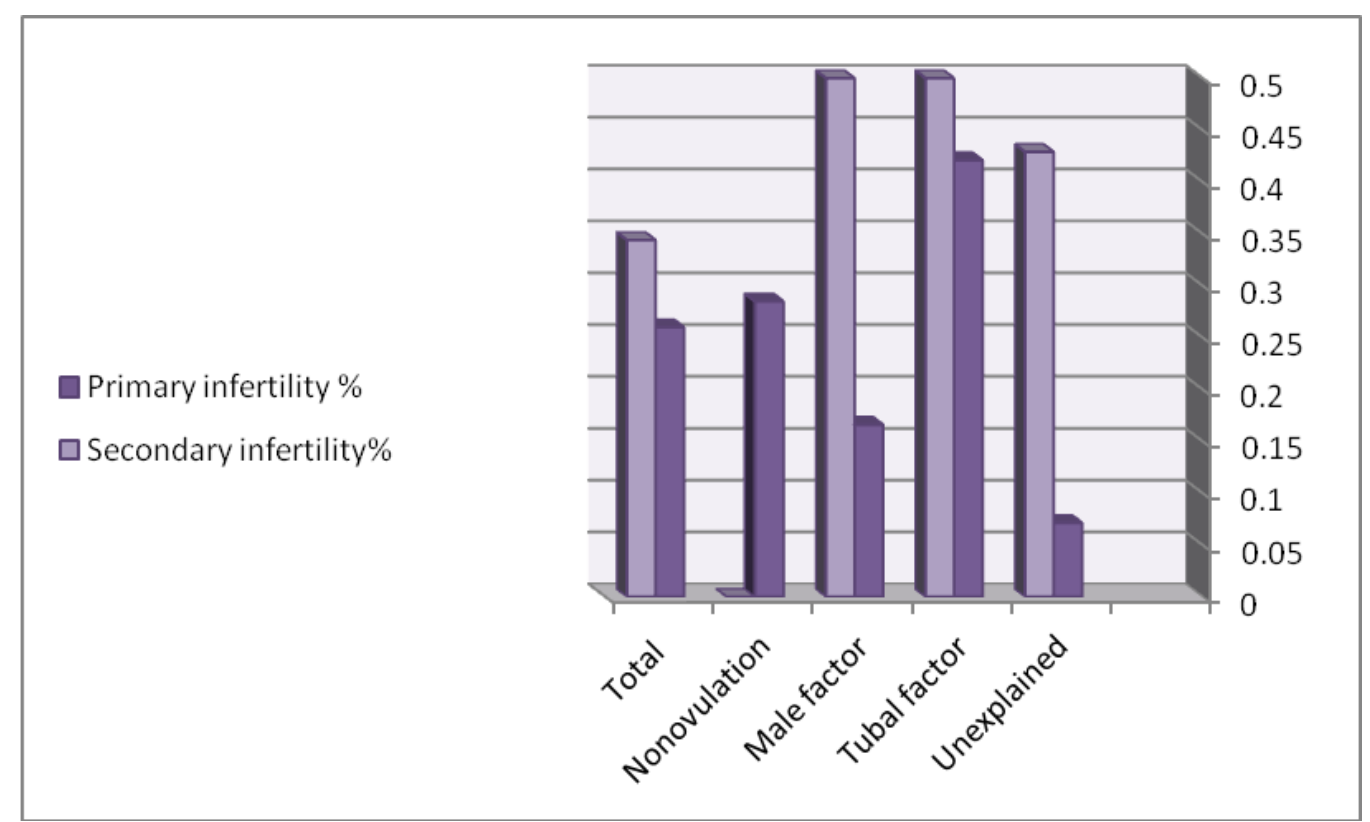

Figure 3: Cause of infertility in the primary and secondary infertility groups, with the results of polymerase chain reaction testing for Chlamydia trachomatis 


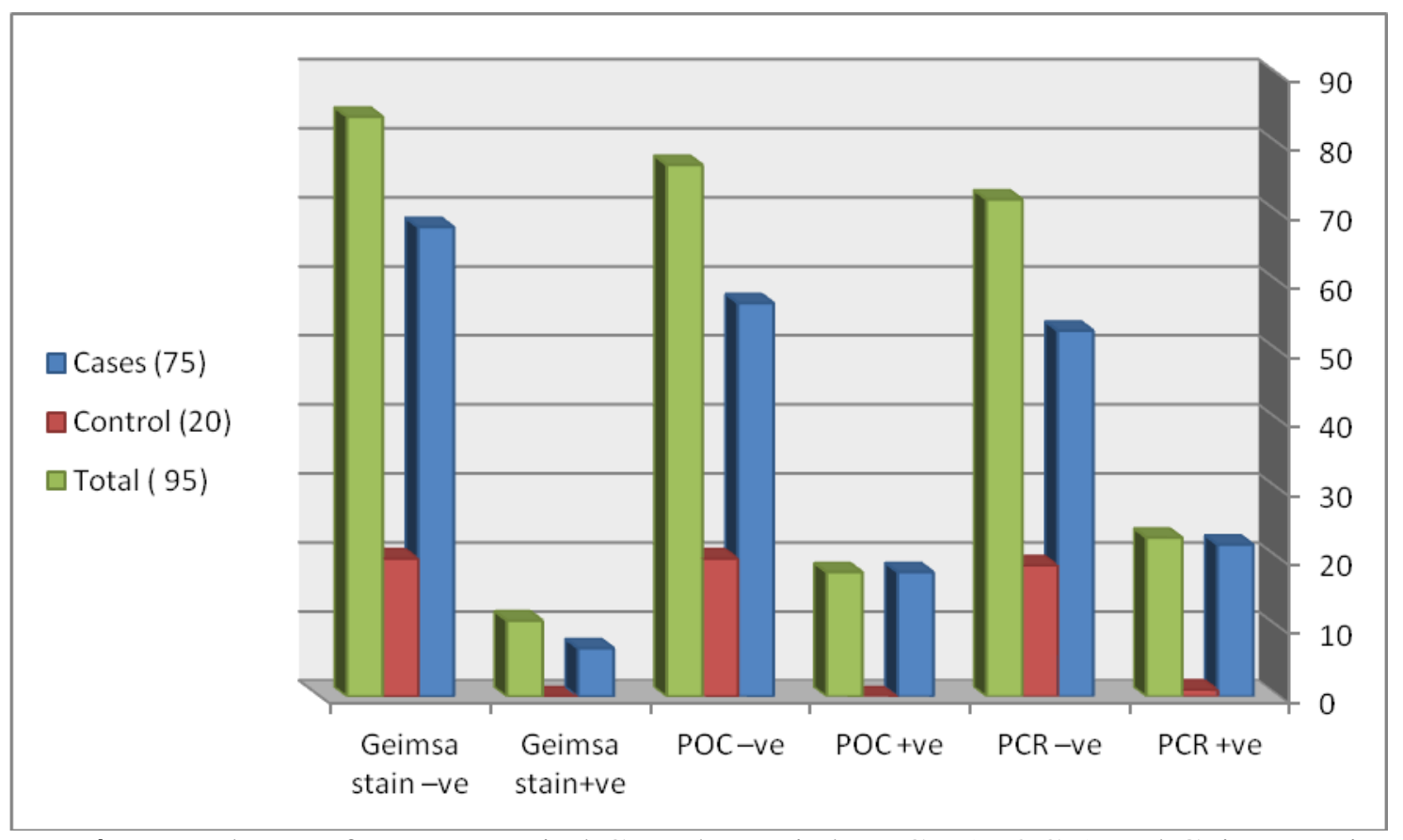

Figure 4 : Prevalence of current genital C trachomatis by PCR ( POCT) and Geimsa stain

\section{DISCUSSION}

The present results revealed statistically significant association between current $C$. trachomatis infection with clinical manifestations of infertility in a sample of infertile Egyptian women. The study showed that the overall prevalence of genital C.trachomatis by PCR was (22/75)29.3\% in infertile women and 1/20 (5\%) in control fertile subjects with a significant difference between both groups as well as the C.trachomatis rapid point of care test was able to detect (18/75) 24\%.This was in line with Agha et al. (2011) who found that 18 cases out of 70 Egyptian females attending outpatient gynecology clinic Mansoura university hospital positive when tested for genital C.trachomatis by PCR (25.7\%). As well as higher isolation rates ranged from $26,9 \%$ to $36.2 \%$ was detected in aetiologically unexplained asymptomatic infertile women in a WHO study that reported the current c.trachomatis infection in infertile women to be 18-20\%. (Marconi et al., 2008 and Paavonen 2011) Studies about the prevalence of C.trachomatis in the Arab world are quite limited. Kamel (2013) reported that The prevalence of Chlamydia trachomatis infection among infertile women in Saudi Arabia was high(15\%).by PCR.The rate of chlamydia infection detected by ELISA was $(9.84 \%)$ and it was $(12.03 \%)$ by the culture method $(P=$ 0.2443 AL-Thani et al. (2013) documented the prevalence of $C$ trachomatis infection was 5.3\% among Qatari women and 5.5\%among non Qatari women but they did not correlate its presence with any gynecological abnormality or infertility. Studies in women from northern India revealed high infection rate of C.trachomatis (27\% 20of 74) in women with primary infertility as detected by culture or antigen test (Malik $\boldsymbol{e t}$ al., 2006.) Other studies recently reported Mania-Pramanik $\boldsymbol{e t}$ al. (2012) revealed significant statistical association between current C.trachomatis infections with infertility. Average infection rate was $12.1 \%$, highest in women with infertility (18.6\%) as detected by PCR.

But this recent study was not in line with Siam and Hefzy (2011) who found that the PCR prevalence of current genitourinary C.trachomatis was $4.4 \%$ in infertile Egyptian women and $7.5 \%$ in control subjects with no significant difference between both groups. An explanation for the difference between this present result and the results reported by Siam 
and Hefzy (2011) may be attributed to the difference in the study population, male partner infection, the sensitivity of the laboratory method used as well as the type of sample collected. The variation observed of $\mathrm{C}$ trachomatis prevalence between Middle Eastern studies as well as rest of the world could be due to study population (educational level, sample size), rate of infection in the study area, hygiene level and socioeconomic status of the study area, culture of the society and the technique used for the detection.

Tubal factor as a cause of infertility in the studied case group was the highest cause of infertility $29 / 75(38.6 \%)$ and $C$. trachomatis PCR positive results was high among this group 13/29 (44.8\%). This is in accordance with Bebear and Barbeyrac (2009) who reported that one third of ectopic pregnancies are associated with C.trachomatis infection. As well as El-Shorbagy et al. (2010) reported that that incidence of Chlamydial infection was 51.8\% among tubal infertility subjects and Mania-Pramanik et al. (2012) reported that one fourth of ectopic pregnancies are associated with current $C$ trachomatis infection.

C.trachomatis is a common cause of cervicitis and uretheritis, and sequeleae include pelvic inflammatory disease, ectopic pregnancy ad tubal factor infertility (Carey and Beagley 2010)

This study showed the prevalence of current genital C.trachomatis by PCR in 1ry infertility was $12 / 46(26 \%)$ and in 2ry infertility was10/29(34.4\%) and this difference was not statistically significant this is in line with results reported with Siam and Hefzy (2011).

C.trachomatis is the most common bacterial cause of sexually transmitted infections. Genetic predisposition and host immune response play important roles in the pathogenesis of long term complications after C.trachomatis infections. (Bas et al., 2008; Brocklehurst and Rooney 2002)

This study investigated the relationship between past C.trachomatis (examined by anti C.trachomatis antibodies IgG assay detected by ELISA) and infertility in asymptomatic Egyptian women with primary and secondary infertility. It revealed that prevalence of anti C.trachomatis $\mathrm{IgG}$ in asymptomatic infertile and control women was $27 / 75$ (36\%) and $2 / 20(10 \%)$ respectively. This result is in line with previous studies performed by Siam and Hefzy (2011) who found IgG antibodies to C.trachomatis were $31.1 \%$ of the infertile Egyptian women.

In another study, higher prevalence rates for ACTA IgG than the present study was present Anti chlamydial IgG antibodies were present in $68 \%$ of women with infertility. Where Chlamydia IgG antibodies have been found in 30-60\% of subfertile women and are considered as markers for past pelvic infections. (Mittal et al., 2010; Olsen et al., 2010). No explanation for this striking high prevalence was found except that might be misinterpretation of results or the difference in the study population.

Hernandez Trejo et al. (2009) identified that a titer greater or equal to 1:152 of anti Chlamydia IgG antibodies could be used to differentiate tubal damage infertility from other causes of subfertility in a group of Mexican women. Sonmez et al. (2008) found a positive correlation between high Chlamydia trachomatis antibodies and tubal damage. As well as Jeremiah et al. (2011) concluded that there is a strong association between Chlamydia antibody positivity and tubal occlusion.

In this study higher prevalence of anti $\mathrm{C}$ trachomatis $\mathrm{IgG}$ was found in the serum of 1ery infertility women $18 / 46$ (39.1\%) than 2ry infertility women $9 / 29$ (31.03\%). However, the difference between both groups was not significant $(\mathrm{P}=0.87)$ this was in line with Siam and Hefzy 2011 who found no statistical significant difference between anti $\mathrm{C}$ trachomatis IgG antibodies between primary and secondary infertility although they were found high 
prevalence of anti $\mathrm{C}$ trachomatis IgG antibodies in serum of secondarily infertile women than primary infertility patients. The difference between these results and this study may be attributed to difference between the sample sizes

As C.trachomatis is an obligate intracellular pathogen, cell culture remains the reference method and it has $100 \%$ specificity but it is not recommended for routine use because of its technical; complexity, the long turn-around time and it is unsuitable in developing countries. Therefore many commercial non -culture-based assays are now available for diagnosis. (Carder et al., 2006)

Bebear and Barbeyrac (2009) concluded that the diagnosis of C.trachomatis is best made by using nucleic acid amplification tests , because they perform well and do not require invasive procedures for specimen collection.

The Chlamydia Rapid Test is an immunoassay based test that detects Chlamydia lipopolysaccharide (Michel $\boldsymbol{e t}$ al., 2006). This new test provides a same day result, which would allow immediate treatment of the infected patient. Unlike other rapid tests, the novel signal amplification system of the Chlamydia Rapid Test maximises the visual test signal, and the improved sample preparation chemistry overcomes signal inhibition caused by the high viscosity and variability of vaginal fluid. Specimen types for Chlamydia trachomatis testing have evolved in recent years, as studies have shown that vaginal specimens perform as well as, if not better than, endocervical swabs or first void urine across a range of nucleic acid amplification tests. (Shafer $\boldsymbol{e t}$ al., 2003)

With the Chlamydia Rapid Test, results are available within 30 minutes, allowing all patients testing positive to be offered treatment while still at the clinic. Given that about $3 \%$ of women diagnosed with Chlamydia infection have been found to develop pelvic inflammatory disease in the interval between testing and their return for treatment. The prompt treatment of infected women made possible by the Chlamydia Rapid Test would be expected to avert this outcome. (CDC 2002)

This study compared the prevalence of Current genital $C$ trachomatis by PCR and rapid POCT in the infertile and control subjects and it reported that PCR was able to detect $29.3 \%$ (22/75 patients) whereas rapid point of care was able to detect 24\% (18/75 patients)

On comparing the sensitivity, specificity, PPV and NPV of the rapid point of care test in comparison to PCR it revealed that $81.8 \%, 98.1 \%, 94.7 \%$ and $92.9 \%$ respectively. The chlamydia trachomatis POCT gave one false positive result and failed to detect four cases (false negative results.

This results are nearly in line with Mahilum-Tapay (2007) who Compared chlamydia trachomatis POCT with polymerase chain reaction assay, and found sensitivity, specificity, positive predictive value, and negative predictive value of the Chlamydia Rapid Test were $83.5 \%$ (91/109), 98.9\% (1224/1238), 86.7\% (91/105), and 98.6\% (1224/1242) the slight difference between the two studies may be due to the difference in the size of the studied population, the type of the sample collected. Huang et al. (2013) reported that the sensitivity and specificity of the experimental vaginal POC test were $92.9 \% 98.5 \%$, respectively. The positive and negative predictive values were $86.7 \%$ and $99.2 \%$ respectively. The difference in the results may be attributed to the way and type of sample collected.

The present study reported that Giemsa stain was able to detect $7 / 75$ cases $(9.3 \%)$ in comparison to $29.3 \%$ to PCR and 24\% to the rapid POCT this is in line with Mohammad zadeh et al. (2011) who failed to detect Chlamydia with Giemsa stain when compared it 
with PCR and immunofluorescence assay and concluded that Giemsa staining is not a suitable and reliable technique for chlamydia trachomatis detection.

As a final conclusion, we find a strong relationship between past and current C.trachomatis infection and infertility in a sample of Egyptian infertile women. No difference was found in the prevalence of current or past C.trachomatis infection and fertile controls. The Chlamydia rapid test achieves relatively high diagnostic sensitivity and provides results within 30 minutes. It is suitable as primary diagnostic tool for Chlamydia infection and in settings where PCR tests is limited or absent thus it could be used as a screening tool.

There is a need to address this invisible and poorly quantified cause of infection among the infertile women on a wide scale.

\section{REFERENCES:}

Agha, A.S.; El-Mashad, N.; Rakha A. S.; and El Metwally G. A. (2011): Value of direct antigen detection methods in diagnosing women with suspected genital Chlamydia trachomatis infection African Journal of Microbiology Research; 5(10): 1215-1219.

Al- Thani, A.; Abdul Rahim, H.; Alabsi, E; Bsaisu, N.H.; Haddad, P.; Mumtaz, R.G and Abu-Raddad, J.L. (2013): Prevalence of chlamydia trachomatis in the general population of women in Qatar. Sex.Trans.doi:10.1136/ sextrans-2013-051169

Al-Sweih, N. A.; Khan, S. and Rotimi, V. (2011): Prevalence of Chlamydia trachomatis and Neisseria gonorrhoeae Among Asymptomatic Women Attending the Capital Health Region Clinics in Kuwait. Sexually Transmitted Diseases 38(9): 793-797

Abu-Raddad, L.; Akala, F.A.; Riendner, G.; Semini, I.; Tawil, O. and Wilson, D. (2010): Characterizing the HIV/AIDS epidemic in the Middle East and North Africa: time for strategic action, Middle East and North Africa HIV/AIDS Epidemiology Synthesis Project. World Bank/UNAIDS/WHO Publication. Washington, DC: The World Bank Press.

Bas, S.; Neff, L.; Vuillet, M.; Spenato, U.; Seya, T.; Matsumoto, M. and Gabay C. (2008): The proinflammatory cytokine response to Chlamydia trachomatis elementary bodies in human macrophages is partly mediated by a lipoprotein, the macrophage infectivity potentiator, through TLR2/TLR1/TLR6 and CD14. J Immunol. 15; 180(2):1158-68.

Bébéar, C. and Barbeyrac, B. (2009): Genital Chlamydia trachomatis infections. Clin. Microbiol. Infect. 15: 4-10.

Böhm, I.;Gröning, A.;Sommer, B.; Müller, H.W.;Krawczak, M.;Glaubitz, R. (2009): A German Chlamydia trachomatis screening program employing semi-automated real-time PCR: results and perspectives. J ClinVirol; 46 (3):S27-32.

Carder, C.; Mercey, D. and Benn, P. (2006): Chlamydia trachomatis. Sexually transmitted infect, 82(4): 10-12.

Carey, A.J. and Beagley, K.W. (2010): Chlamydia trachomatis, a hidden epidemic: effects on female reproduction and options for treatment. Am J ReprodImmunol ; 63(6): 576-86 
Centers for Disease Control and Prevention. (2002): Sexually transmitted disease treatment guidelines. MMWR RecommRep; 51:1-78.

Center for Disease Control and Prevention (CDC) (2009): Chlamydiasscreening among sexually active young female enrollees of healthplans-United States, 2000-2007. MMWR Morb Mortal Wkly Rep. 17;58(14): 362-365

Chavez-Badiola, A.; Drakeley, A.J.; Finney, V.;Sajjad, Y. and Lewis-Jones, D.I (2008): Necrospermia, antisperm antibodies, and vasectomy. FertilSteril.; 89(3):723.e5-7.

Dutta, R.;Jha, R.; Salhan, S. and Mittal, A. (2008): Chlamydia trachomatis-specific heat shock proteins 60 antibodies can serve as prognostic marker in secondary infertile women. Infection; 36(4):374-8.

El-Shourbagy, M.; Abdel-el-Maebound, K.; Diab, K.M.; El Ghannam, A.; Nabegh, L.and Ammar, S. (1996): Genital Chlamydia trachomatis infection in Egyptian women: Incidence among different risk groups. J ObstetGynecol Res; 22 (5):467-472.

Gunyeli, I.; Abike, F. and Dunder, I. (2011): Chlamydia, Mycoplasma and Ureaplasma infections in infertile couples and effects of these infections on fertility. Arch Gynecol Obstet.; 283(2): 379-85.

Haggerty, C.L.; Gottlieb, S.L.; Taylor, B.D.; Low, N.; Xu, F. and Ness, R.B. (2010): Risk of sequelae after Chlamydia trachomatis genital infection in women. $J$ Infect Dis. 15; 201 S134-55.

Hernandez-Trejo, M.; Lopez-Hurtado, M.; Artaeaga-Tronscoso, G. and Guerra-Ingante F.M. (2009): Anti-CtrachomatisIgG antibodies levels in serum to identify infertility caused by tubal damage. Rev Invest Clin 61(1):87-9

Huang, W.; Gaydos, C. A.; Barnes, R. M.; Jett-Goheen, M.; and Diane R. B. (2013): Comparative effectiveness of a rapid point-of-care test for detection of Chlamydia trachomatis among women in a clinical setting 9 Sex Transm Infect. 89(2): 108-114. Published on line 2012 September 14. doi: 10.1136/sextrans2011-050355

Huppert, J.;Hesse, E. and Gaydos, C.A. (2010): What's the point? How point-of-care STI tests can impact infected patients. Point Care; 9:36-46

Hsieh, Y.H.; Gaydos, C.A.; Hogan, M.T.; Uy, O.M.;Jackman, J.; Jett- Goheen, M.; Albertie, A.; Dangerfield D.T.; Neustadt, C.R.; Wiener, Z.S. and Rompap, A.M. (2011): What qualities are most important to making a point of care test desirable for clinicians and others offering sexually transmitted infection testing? PLoS One 29; 6(4):e19263.

Jeremiah, I.; Oike, O. andAkani, C. (2011): The prevalence of serum immunoglobulin G antibody to Chlamydia trachomatis in subfertile women presenting at the university of Port Harcourt teaching Hospital, Nigeria. Int J. Biomsci 7(2):120124

Kamel, R.M. (2013): Screening for Chlamydia trachomatis infection among infertile women in Saudi Arabia. International Journal of Women's Health $5: 277-284$, http://dx.doi.org/10.2147/IJWH.S46678

Lahiri, D.K. and Nurnberg, JI. Jr.(1991): A rapid non enzymatic method for the preparation of HMW DNA from blood for RFLP studies. Nucleic acids Res; 19(19):5444 
Lau, C.Y. and Qureshi, A.K. (2002): Azithromycin versus doxycycline for genital chlamydial infections: a meta-analysis of randomized clinical trials. Sex Transm Dis; 29:497-502.

Mahilum-Tapay, L.; Vivian, L.; James, J. W. and Alison,S. (2007): New point of care Chlamydia Rapid Test-bridging the gap between diagnosis and treatment: performance evaluation study, BMJ. 2007 December 8; 335(7631): 1190-1194. Published online 10.1136/bmj.39402.463854.

Malik, A.; Jain, S.; Hakim, S.; Shukla, I.; Rizvi, M. (2006): Chlamydia trachomatis infection \& female infertility. Indian J. Med. Res., 123: 770-775.

Malik, A.; Jain, S.; Rizvi, M.; Shukla, I. and Hakim, S. (2009): Chlamydia trachomatis infection in women with secondary infertility. FertilSteril.; 91(1):91-5.

Mania-Pramanik, J.; Potdar, S and Kerkar, S. (2006): Diagnosis of Chlamydia trachomatis infection. J. Clin. Lab. Anal; 20: 8-14.

Mania- Pramanik, J.; Kerkar, S.; Sonawane, S.; Mehta, P. and Salvi, V. (2012): Current Chlamydia trachomatis Infection, A Major Cause of Infertility,JReprodInfertil; 13(4): 204-210. PMCID: PMC3719340

Marconi, M.; Nowotny, A.; Pantke, P.; Diemer, T.and Weidner, W. (2008): Antisperm antibodies detected by mixed agglutination reaction and immunobead test are not associated with chronic inflammation and infection of the seminal tract. Andrologia.; 40(4):227-34.

McFarland, W.; Abu-Radded, L. J.; Mahfoud, Z.; Dejong, J.; Riedner, G.; Forsyth, A. and Khoshnood, K. (2010): HIV /AIDS in the Middle East and North Africa: new study methods, results, and implications for prevention and care. AIDS 24:S1-4.

Michel, C.E.; Solomon, A.W.; Magbanua, J.P. V.; Massae, P.; Huang, L.; Mosha, J.; West, S.K.; Nadala, E.C.; Baily, R.; Wisniewski, C.; Mabey, D.C.; and Lee, H.H. (2006): Field evaluation of a rapid point-of-care assay for targeting antibiotic treatment for trachoma control: a comparative study. Lancet; 367:158590.

Mittal, V.; Agarwal, J.; Jain, A. and Verma, A.K. (2010): Prevalence of genital Chlamydia trachomatis in women using PCR on urine specimen. Biomedical Research; 21 (3): 301-304.

Mohammadzadeh, M.;Amirmozafari, N.; Shayanfar, N.; Ranjbar, R.and Rahbar'M. (2011): Prevalence of Chlamydia trachomatis infections in symptomatic women by polymerase chain reaction (PCR)immunofluorescence and Giemsa stain. African Journal of Biotechnology Vol. 10 (34), pp. 6601-6605

Munday,P.E.; Johnson,A.P.; Thomas, B.j. and Taylor, R. (1980): A comparison of the sensitivity of immunofluorescence and Giemsa for staining chlamydia trachomatis inclusion in cycloheximide treated Mccoy cells. J.Clin.Pathol; 33:177-179.

Olsen, A.W.; Theisen, M.; Christensen. D.; Follmann, F. and Andersen P. (2010): Protection against Chlamydia promoted by a subunit vaccine (CTH1) compared with a primary intranasal infection in a mouse genital challenge model. PLoS One.; 5(5):e10768. 
Paavonen, J. (2011): Chlamydia trachomatis infections of the female genital tract: State of the art. Ann Med. Feb 1.

Schachter, J. (1997): DFA, EIA, PCR, LCR and other techniques: what tests should be used for diagnosis of Chlamydia infections? Immunological investigations; 26: 157-161

Shafer, M.A.; Moncada, J.; Boyer, C.B.; Betsinger, K.; Flinn, S.D. and Schachter J. (2003): Comparing first-void urine specimens, self-collected vaginal swabs, and endocervial specimens to detect Chlamydia trachomatis and Neisseria gonrrhoeae by a nucleic acid amplification test. J Clin Microbial; 41:4395-9.

Siam, M. E. and Hefzy, M.E. (2011): The Relationship between Antisperm Antibodies Prevalence andGenital Chlamydia trachomatis Infection in Women withUnexplained Infertility, African Journal of Reproductive Health; 15(3): 93

Sonmez, S.; Sonmez, E.; Yaser, L.; Aydin, F.; Coskum, A. and Sut, N. (2008): Can screening Chlamydia trachomatis by serological tests predict tubal damage in infertile patients. New Microbiol 31(1): 75-9

Swain, G.R.; McDonald, R.A.;Pfister, J.R.; Grdus, M.S.; Sedmak, G.V. and Singh A. (2004): Decision analysis: point-of-care Chlamydia testing vs laboratory-based methods. Clin Med Res; 2:29-35.

World Health Organization. (2013): Global prevalence and incidence of selected curable sexually transmitted infections: Overview and estimates. Geneva, Switzerland: WHO.

$$
\begin{aligned}
& \text { معدل انتشار عدوى Chlamidia Trachomatis في النساء العاقرات في مصر } \\
& \text { 1اجدة رمضان - 1ومنال درويش - علعلى شكر }
\end{aligned}
$$

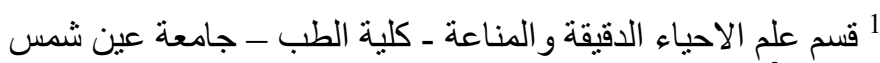

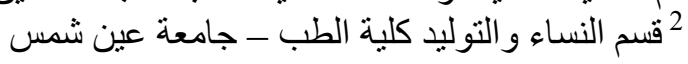

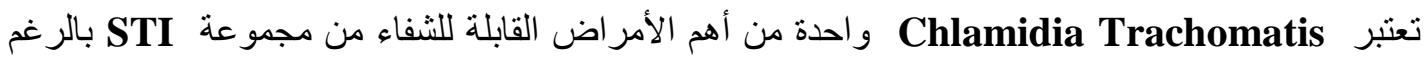

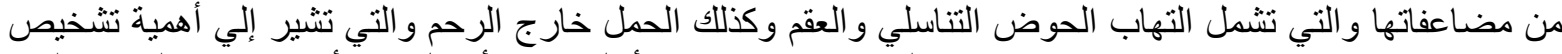
Chlamidia Trachomatis

العلاقة بين حالات Chlamidia Trachomatis السابقة أو الحالية كسبب في حالات العقم عند النساء المصريات . وذللك من أجل أن يضع الأطباء Chlamidia Trachomatis من أحد الأسباب المقارنة في حالات العقم

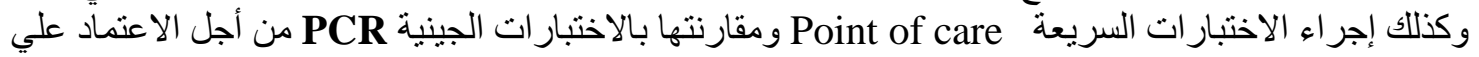

$$
\text { Point of care }
$$

وقد اجري هذا البحث علي النساء في عيادات النساء الخاصة بالعقم في مستشفي الدمرداش في الفترة من يناير

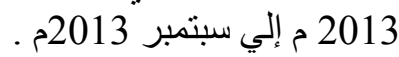

وتثنمل المجموعة المرضية 75 حالة و المجموعة الضابطة 20 حالة وقد اجري لهم فحص النساء الروتيني

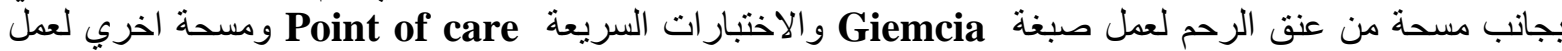

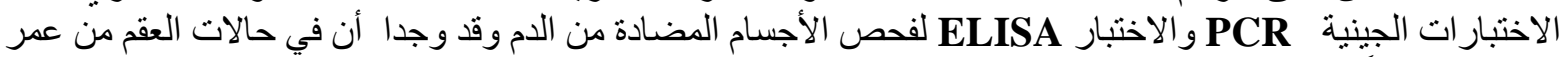

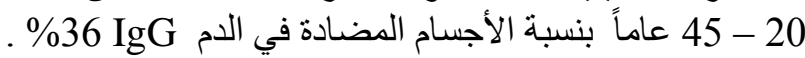

الاختبار الجيني PCR \% 29.3 PCR واختبار الفحص السريع Point of care بنسبة 24\% ـ

ويستنتج من ذلك أنه يوجد علاقة قوية بين وجود Chlamidia Trachomatis وحالات العقم عند النساء

وان التشخيص السريع ل Point of care يعطي نتيجة حسنه و سريعة خلال 30 دقيقة يعتبر ذللك تشخيص مبدئي

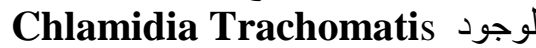

